Удк 316. 44

DOI: https://doi.org/10.32840/1814-1161/2020-2-7

Budiakova Olena

Candidate of Economic Sciences,

Senior Lecturer at the Department

of Business Economics and Tourism

Kyiv National University of Technology and Design ORCID: https://orcid.org/0000-0001-6028-2650

Shaposhnikova Olena

Candidate of Sciences in Public Administration, Associate Professor

National Technical University Dniprovsk Polytechnic ORCID: https://orcid.org/0000-0001-9146-0069

Будякова О.Ю.

кандидат економічних наук, старший викладач кафедри бізнес-економіки та туризму Київського національного університету технологій та дизайну

Шапошнікова О.М.

кандидат наук з державного управління, доцент Національний технічний університет «Дніпровська політехніка»

\title{
CURRENT PROBLEMS OF ECONOMIC DEVELOPMENT OF UKRAINE
}

\section{СУЧАСНІ ПРОБЛЕМИ ЕКОНОМІЧНОГО РОЗВИТКУ УКРАЇНИ}

The article establishes that the main task of structural restructuring of the Ukrainian economy is to form a modern, efficient, rational, environmentally sound structure of the economy and to create competitive domestic production based on the realization of absolute and relative advantages of the country. The main task of the current period, which is to manage economic reforms and create a socially oriented market economy, has been updated. The necessary effective tools for the implementation of this course and overcoming the current problems of economic development of Ukraine are offered. It is substantiated that in the conditions of rapid development of the latest technologies, investment is the most important means of ensuring progressive structural shifts in the economy, and the stabilization and development of the state's economy depend to a large extent on how effective the investment activity is. The basic requirements for the formation of an effective sectoral structure of the economy are determined. For this purpose, the economic complex of Ukraine and the volume of foreign direct investment in Ukraine in the recent period are characterized. The position of Ukraine in the major world rankings and prospects for further dynamics are presented. The article substantiates the measures of the state on structural reforming of the economy aimed at improving the management of investment processes.

Keywords: economics, investments, investment climate, economic complex.

В статmі встановлено, що основне завдання структурної перебудови економіки України полягає у формуванні сучасної, ефрективної, раціональної, екологічно безпечної структури економіки та створенні конкурентоздатного вітчизняного виробництва на основі реалізації абсолютних та відносних переваг країни. Актуалізовано головне завдання поточного періоду, яке полягає в наданні керованості економічними реформами та створенні соціально-орієнтованої ринкової економіки. Запропоновано необхідні дієві інструменти для реалізації цього курсу та подоланні сучасних проблем економічного розвитку України. Обґрунтовано, що в умовах стрімкого розвитку новітніх технологій інвестиції є найважливішим засобом забезпечення прогресивних структурних зрушень в економіці, а стабілізація та розвиток економіки держави значною мірою залежать від того, наскільки ефрективною є інвестиційна діяльність. Визначено основні вимоги для формування ефективної галузевої структури економіки. Для цього охарактеризовано господарський комплекс України та обсяги прямих іноземних інвестицій в Україну за останній період. Наголошено, що світова економічна криза має вплив на погіршення економічної ситуації України, тому покращення інвестиційного клімату в Україні неможливе без ефективного регулювання інвестиційної діяльності державою. Представлено положення України в основних світових рейтингах та охарактеризовані перспективи подальшої динаміки. Визначено стратегічне завдання державного управління інвестиційною діяльністю, вирішення якого спрямоване на стабілізацію та прогресивний розвиток економіки; реструктуризацію його господарського комплексу, створення привабливих умов інвестиційної діяльності. З'ясовано, що для 
виконання цього завдання доцільно активізувати інвестиційну діяльність, що є пріоритетною умовою стабільного розвитку, яка здатна залучити фрінансові та матеріальні ресурси як вітчизняних, так й іноземних інвесторів, а також раціонально використовувати їх у найбільш пріоритетних галузях економіки. В статті обгрунтовано заходи держави щодо структурного реформування економіки, спрямовані на вдосконалення управління інвестиційними процесами.

Ключові слова: економіка, інвестиції, інвестиційний клімат, господарський комплекс.

В статье доведено, что основная задача структурной перестройки экономики Украины заключается в фрормировании современной, эффрективной, рациональной, экологически безопасной структуры экономики и создании конкурентоспособного отечественного производства на основе реализации абсолютных и относительных преимуществ страны. Актуализирована главная задача текущего периода, которая заключается в представлении управляемости экономическими реформами и создании социально-ориентированной рыночной экономики. Предложены необходимые действенные инструменты для реализации этого курса и преодолении современных проблем экономического развития Украины. Обосновано, что в условиях стремительного развития новейших технологий инвестиции являются важнейшим средством обеспечения прогрессивных структурных сдвигов в экономике, а стабилизация и развитие экономики государства в значительной степени зависят от того, насколько эфрфективной является инвестиционная деятельность. Определены основные требования для фрормирования эфрфективной отраслевой структуры экономики. Для этого охарактеризованы хозяйственный комплекс Украины и объемы прямых иностранных инвестиций в Украину за последний период. Представлены положения Украины в основных мировых рейтингах и охарактеризована последующая динамика. В статье обоснованы меры государства по структурному реформированию экономики, направленные на совершенствование управления инвестиционными процессами.

Ключевые слова: экономика, инвестиции, инвестиционный климат, хозяйственный комплекс.

Formulation of the problem. With the rapid development of new technologies, investment is the most important means of ensuring progressive structural shifts in the economy. Stabilization and development of the state's economy depend to a large extent on how effective the investment activity is. In this, a significant role is played by the state, which, by means of economic regulation, has the ability to purposefully influence not only the formation of domestic and foreign investment inflows, but also create the conditions for their direction in the real sector of the economy. Solving the problem of investing will enable progressive restructuring at all levels, transition to a highly developed economy, that is, to innovative development. Strategic investment policy is regarded as the most important component of the general economic policy pursued by the state. The problems of increasing the competitiveness of regions in an open economy, the ability of central and local authorities to implement regional investment policy are important in this context.

Effective public investment policy also involves the use of public investment as a means of creating the primary conditions for attracting private and foreign investment in the development of priority sectors of the economy. Particular attention is given to investment projects with mixed investments, using the state share of investment as a guarantee of targeted investment resources.

The main direction of increasing the level of investment security should be to change the sectoral structure of investments in favor of industries that have been recognized as priorities in the process of structural adjustment. In turn, the state should manage the process of investing in production, because it is the state of the investment sector that shapes the factors of production that determines the intensity of economic growth.

Analysis of recent research. The question of the economic development of Ukraine is not new enough for the domestic economy, and therefore, among the literature sources, there are studies of domestic authors, such as: Belovodskaya O.A., Voronkova T.E., Gryshchenko I.M., Denysenko M.P., Ilyashenko S.M., Kuzmin O.E., Fedorenko V.G., etc. But the scientific literature does not sufficiently cover aspects of the formation of an open economy. Therefore, it becomes relevant to disclose the essence of foreign direct investment and their receipt in Ukraine.

Formulating the goals of the article. Ukraine, as the European country, seeks to integrate into the EU. However, this organization is making such demands on its potential members that Ukraine is still unable to satisfy. The main task of the current period is to provide guidance to economic reforms and to create a socially-oriented market economy based on the revival and accelerated development of promising sectors of domestic production, modeling it by the criterion of economic growth.

Presenting main material. The main factor that determines the need for a radical reform of the domestic economy and increase its competitiveness is the choice of a course on the formation of an open economy and integration into the world economic structures. The implementation of this course is hindered by the imperfection of forms and methods of state regulation of economic development [1, p. 54], shortcomings of the tax system, lack of investment resources [2, p. 30], weak innovation activity [3, p. 37], the lack of results expected from privatization, the practical absence of the results of administrative reforms and institutional changes. Therefore, the main task of the current period is to provide guidance to economic reforms and to create a socially oriented market economy [4; 5], based on the revival and accelerated development of promising sectors of domestic production, modeling it by the criterion of economic growth.

The main task of structural restructuring of the economy of Ukraine are to form a modern, efficient, rational, environmentally sound structure of the economy and to create competitive domestic production based on 
the realization of absolute and relative advantages of the country. These require:

1. Production modernization, its technical and technological updating.

2. Reduction of resource (production, material, energy) production.

3. Changing the relationship between the manufacturing of means of production and consumer goods in favor of the latter.

4. Creating conditions for investment.

5. Enhancing the technological integrity of enterprises and industries, ensuring a closed cycle of production.

The optimal development of the structure of the Ukrainian economy requires a systematic approach that includes certain areas of improvement of structural adjustment.

The formation of an effective sectoral structure of the economy involves:

1. Elimination of hypertrophied imbalances between the real and financial sectors of the economy, as well as within each of them.

2. Prevailing development of industries that meet people's needs.

3. Broad development of services.

4. Creation and development of high-tech industries.

5. Development of processing industries on a new technical and technological basis.

6. Development of export and import substitution industries.

7. Development of priority (key) sectors of the national economy.

Ukraine is a potentially rich country that is selfaware and perceived from the outside as a political and economic state at the level of Poland and Turkey. Among the former USSR republics, Ukraine has inherited one of the best sets of source resources.

The economic complex of the country includes such types of industry as: heavy engineering, ferrous and non-ferrous metallurgy, shipbuilding, aviation, production of buses, cars and trucks, tractors and other agricultural machinery, locomotives, machine tools, turbines, equipment for power plants, oil and gas and chemical industry, etc. In addition, Ukraine is a powerful producer of electricity. Ukraine is a major manufacturer of military equipment: tanks, military transport aircraft, anti-aircraft missile systems, optical equipment.

Ukraine is a transit country through which 5 of the 10 international transport corridors of Europe pass. There are developed all modern modes of transport: rail, road, river, sea, pipeline and air.

The volume of direct foreign investments in Ukraine in the form of share capital as of October 1, 2019 was 34.73 billion USD, which was 1.82 billion USD, or $5.5 \%$, higher than at the beginning of the year, the State Statistics Service reported.

According to its data, the first half of the year there were received 1.67 billion USD in investments, 0.98 million USD in withdrawals, but most of the gain was provided by the exchange rate difference for strengthening the hryvnia: 1.14 billion USD.

As it was reported, in the first quarter of 2019 , foreign direct investment in Ukraine increased by only
$\$ 45.5$ million. Their revenues were 0.59 billion USD, withdrawals were $\$ 0.5$ billion, and the exchange rate difference was 0.06 billion USD.

According to the results of six months, the growth of foreign direct investments amounted to 0.84 billion USD: investment receipts -1.26 billion USD, withdrawals 0.73 billion USD with a foreign exchange difference of 0.52 billion USD.

According to the State Statistics Service, the largest increase in foreign direct investment in January-September 2019 was recorded from Cyprus 761.1 million USD (up to 10.3 billion USD), the Netherlands - 438.3 million USD (up to 7.56 billion USD), the Russian Federation - 220.1 million USD (up to 0.82 billion USD) and Switzerland - 133.3 million USD (up to 1.68 billion USD).

At the same time, there was a sharp decrease in investments from Hungary - by $\$ 197.8$ million (up to $\$ 0.37$ billion) and the United Kingdom - by $\$ 92.7$ million (up to $\$ 2.04$ billion).

By sector, the largest growth in foreign investments was recorded in financial and insurance activities 828.6 million USD, mining and processing industry 266.4 million USD and 235.4 million USD, real estate operations - 225.8 million USD, professional, scientific and technical activities - 161.8 million USD, and in the wholesale and retail trade - 146.9 million USD.

At the same time, administrative and support services reduced their investments by 248 million USD.

The spread of negative trends in the world economy, falling demand and prices in world commodity markets also affected Ukraine and had a very negative impact on the real sector of the economy.

The deep Ukrainian crisis, compounded by the impact of the global financial and economic crisis, is primarily due to serious internal causes that go beyond the financial problems that have escalated into an economic downturn, rising unemployment, and declining living standards for the general population.

Ukraine is ranked 96th among 167 countries in the global prosperity rating of The Legatum Prosperity think tank. This is stated in a message on the organization's website.

According to the analytical data, the weaknesses of Ukraine are education (37th place) and living conditions (69th place). While the weak are social capital, i.e., interpersonal trust and confidence in institutions (148th place) and personal security (145th place).

At the same time, rating compilers believe that business conditions have improved in the country over the decades [6; 7].

However, in the last ten years, Ukraine has dropped to 10 positions. "Neighbors» of Ukraine, according to the rating, were Tunisia and Cuba - 95th and 97th place respectively. Denmark, Norway and Switzerland ranked first. The last places of the index reached the Central African Republic, Yemen and South Sudan.

The rating compilers analyze the state of education and health care, the level of security, personal freedom, the state of the environment, the quality of public services and whether it is easy to do business and innovation in the country.

The Kälin and Kochenov's Quality of Nationality Index (QNI) is the first of its kind to objectively distribute 
the quality of nationalities around the world. It analyzes both internal factors (such as economic power, human development, peace and stability) and external factors (including visa-free travel and the ability to move and work abroad without burdensome procedures) that make one citizenship better than others in terms of legal status, through which you can develop your talents and business [8, p. 47].

Published by Hart, QNI is the result of a successful collaboration between Dr. Christian H. Kälin, Chairman of the Board of Directors of Henley \& Partners, a world leader in residency and citizenship planning, and Professor Dmytro Kochenov, Professor of the European Constitutional Law at Groningen University, The Netherlands, which has a long-standing interest in European and comparative studies of citizenship law. Ukraine ranks 75th in the list of countries, improving by five positions last year.

In the new rating of countries, Ukraine occupies the 75th position with an indicator of $38.2 \%$. The closest "neighbors» of Ukraine on the list are the Republic of Nicaragua (74th place) and Turkey (76th).

The most optimal citizenship, according to the compilers of the rating, is in France with a score of $83.5 \%$. Further there are Germany and the Netherlands with the same indicators in $82,8 \%$. Rating outsiders are Afghanistan (15.4\%) and Somalia (13.8\%). 160 countries are represented in the list.

The QNI (Quality of Nationality Index) analyzes various statistics to understand the opportunities and limitations of each nationality. The index looks at both internal factors (economic scale, human development, public order and stability) and external factors (visa-free access for temporary travel and the possibility of visafree stay and work in other countries) that affect the quality of citizenship.

Ukraine closes the rating on purchasing power of citizens among 42 countries of Europe. On average, one resident of Europe received 14739 EUR in 2019. However, the average Ukrainian has an income of 1830 EUR. As a result, the annual income of the Ukrainians is eight times less than that of the Europeans. Moldova and Kosovo are on par with Ukraine. First place is Liechtenstein. The purchasing power per capita is 67550 EUR. Liechtenstein residents have 4.5 times higher tax-deductible income than other European countries. Second place is for Switzerland. In one of the most expensive cities in the world, purchasing power is 42067 EUR per person. The indicator has been at the same level since last year. Third place is for Luxembourg. In this country, the purchasing power per capita amounted to 35096 EUR. Last year, Iceland was in third place. In 2019, it ranks fourth.

The most important factor that will start to affect the economy of the country from 2021 is the so-called debt vacuum cleaner (the dependence of government debt payments on GDP growth, the figures of which rise sharply after reaching $4-5 \%$ and above), which due to «debt» rescue is restructured in favor of the international speculators of the Ukrainian debt in 2015, will clean up the money that it earns from the country's economies. It is proven by the world practice that it is not possible to grow rapidly (5-7\% per year) and to give $3-5 \%$ of GDP in the form of debt reparations (and other than the word reparations, this cannot be called). In essence, by this decision alone, the past power has obliterated all real and not fictitious prospects for Ukraine's growth until 2040 , if nothing fundamental in the country changes after it with such governance.

Conclusions and prospects for further research.

It is necessary to envisage the following measures of the state regarding structural reform of the economy:

1. Improvement of regulatory support for structural adjustment.

2. Creating favorable conditions for realization of competitive advantages, formation of real national capital.

3. Selection of priority industries, their state support.

4. Macroeconomic stabilization, promotion of progressive structural shifts in the economy.

5. Effective public investment and innovation policy.

6. Development of macroeconomic forecasts for the formation of the modern structure of the economy.

7. Development of national and sectoral structural transformation programs.

8. Rational attraction of foreign capital capable of reforming the structure of the economy.

\section{References:}

1. Denisenko, M.P., Shaposhnikova, O.N. \& Budiakova, O.Yu. (2020). Ekonomichni zakhody derzhavnoho upravlinnia shchodo zaluchennia investytsii [Economic measures of public administration to attract investments]. Naukovyi visnyk: derzhavne upravlinnia - Scientific Bulletin: State management, 1(3), pp. 53-65.

2. Denisenko, M.P. \& Budiakova, O.Yu. (2019). Zaluchennja investycij - vazhlyva skladova ekonomichnogho rozvytku Ukrajiny [Attracting investment is an important component of Ukraine's economic development] Upravlinnja komercializacijeju innovacijnoji produkciji : monoghrafija [Management of commercialization of innovative products: a monograph]. Sums: Tritoria, pp. 28-41.

3. Denisenko, M.P \& Budiakova, O.Yu. (2018). Mekhanizm derzhavnoho upravlinnia innovatsijnoi diial'nosti na rehional'nomu rivni [The mechanism of state management of innovation activity at the regional level]. Naukovyj visnyk: derzhavne upravlinnia - Scientific Bulletin: State management, 1, pp. 34-47.

4. Budiakova O., Babina O., Tsarenok D. (2019) KPIs dlja ocinky socialjnoji vidpovidaljnosti biznesu. [KPIs for assessing corporate social responsibility]. Problemy integhraciji osvity, nauky ta biznesu v umovakh ghlobalizaciji [Problems of integration of education, science and business in the conditions of globalization] (Ukraine, Kyiv, October 4, 2019) pp. 75-76.

5. Budiakova O., Natroshvili S., Kondrateva T. (2019) Systema vzajemodiji sub'jektiv rynku praci dlja zabezpechennja socialjnoji vidpovidaljnosti biznesu. [System of interaction between the subjects of the labor market to ensure the social responsibility of business]. Problemy integhraciji osvity, nauky ta biznesu $v$ umovakh ghlobalizaciji [Problems of integration of education, science and business in the conditions of globalization] (Ukraine, Kyiv, October 4, 2019) pp. 77-78.

6. Denysenko, M., Melnyk, A., Shatskaya, Z., Budiakova, O. (2019). "International regulatory experience business activity". Doslidzhennia ta innovatsii, p. 55-58.

7. Denysenko M., Budiakova O., Kondratieva T. (2019) Foreign experience for economic development small and medium-sized businesses. Paradigm of knowledge. 2019. №5(37). P. 5-16. DOI: $10.26886 / 2520-7474.5(37) 2019.1$ 
8. Denysenko M., Shaposhnikiva O., Budiakova O. (2019) The essence and role of investment business planning in modern economic conditions. Academic notes from KROK University (Economics). no. 1(53), pp. 46-50.

\section{Бібліографічний список:}

1. Денисенко М.П., Шапошнікова О.М., Будякова О.Ю. Економічні заходи державного управління щодо залучення інвестицій. Науковий вісник: Державне управління. 2020. № 1(3). С. 53-65. https://nvdu.undicz.org.ua/index.php/nvdu/article/ view/34/30.

2. Денисенко М.П., Будякова О.Ю. Залучення інвестицій - важлива складова економічного розвитку України / Управління комерціалізацією інноваційної продукції : монографія / за заг. ред. д.е.н., проф. С.М. Ілляшенка, д.е.н., доц. О.А. Біловодської. Суми : Триторія, 2019. С. 28-41.

3. Денисенко М.П., Будякова О.Ю. Механізм державного управління інноваційної діяльності на регіональному рівні. Науковий вісник: Державне управління. 2018. № 1. С. 34-47.

4. Будякова О., Бабіна Т., Царенок Д. KPIs для оцінки соціальної відповідальності бізнесу. Проблеми ін- теграції освіти, науки та бізнесу в умовах глобалізації: матеріали Міжнародної наук.-практ. конф., 4 жовтня 2019 р. Київ : КНУТД, 2019. С. 75-76.

5. Будякова О., Натрошвілі Г., Кондратьєва Т. Система взаємодії суб'єктів ринку праці для забезпечення соціальної відповідальності бізнесу. Проблеми інтеграції освіти, науки та бізнесу в умовах глобалізації: матеріали Міжнародної наук.-практ. конф., 4 жовтня 2019 р. Київ : КНУТД, 2019. С. 77-78.

6. Mykola Denysenko, Alona Melnyk, Zorina Shatskaya, Olena Budiakova International regulatory experience business activity. Research and Innovation: Collection of scientific articles. 2019. Yunona Publishing, New York, USA. p. 55-58. http://conferencii.com/files/ archive/2019-02.pdf

7. Denysenko M., Budiakova O., Kondratieva T. Foreign experienceforeconomic developmentsmall and mediumsized businesses. Paradigm of knowledge. 2019. №5(37). P. 5-16. DOI 10.26886/2520-7474.5(37)2019.1

8. Denysenko M., Shaposhnikiva O., Budiakova O. The essence and role of investment business planning in modern economic conditions. Вчені записки Університету "КРОК" (економічні науки). 2019. Вип. № 1(53). С. 46-50. 